\title{
Meanings of education under occupation: the shifting motivations for education in Palestinian refugee camps in the West Bank ${ }^{1}$
}

\author{
Tejendra Pherali and Ellen Turner \\ Centre for Education and International development, UCL Institute of Education, London, UK
}

\begin{abstract}
Despite being a protracted refugee crisis that entails international debates and controversies, discussions about Palestinian education have frequently sidelined the perspectives, needs and priorities of the Palestinian refugee population. Drawing upon a qualitative study in the West Bankand engaging with theoretical ideas of Johan Galtung, Paulo Freire and Pierre Bourdieu, we argue that the nexus between educational motivation and motivation for Palestinian liberation, which was particularly significant during the periods of 'Palestinian uprising', seems to be declining today in the present day context of oppression and structural violence. The growing disassociation among young refugees with Palestinian liberation, and with education as a means to this liberation, can be seen as a process of symbolic violence. Building upon these findings, we propose a new analytical framework for understanding the interrelationship between education, violence and struggle for social and political transformation in conflict-affected societies.
\end{abstract}

Keywords: Education for Palestinian refugees; structural violence; education for resistance; education and symbolic violence; education and peace building

\section{Introduction}

Education is inherently political, and assumes diverse meanings and roles according to its context and location within power relationships (Apple 1990; Freire 1972). In conflict-affected contexts, the meanings of education hold particular resonance in terms of multifarious links with violence, peace and freedom. The growing body of literature in the field of education and conflict highlights three strands of the interactions between the two: education can be both victim and perpetrator; education can play a key role in the struggle for revolution and liberation against oppression; and education can become peacebuilder (Pherali 2016). Education has traditionally held a position of high importance in Palestinian refugee society. In the context of displacement and adversity, education has become a source of hope and is seen to make valuable contributions to the struggle for life with dignity (Akesson 2014, 192; Alzaroo and Hunt 2003; Fronk, Huntington, and Chadwick $1999,219)$. However, education can also be seen as a 'double-edged weapon; it is both an instrument for oppression and a tool for liberation' (Alzaroo and Hunt 2003, 165).

Subject to the multi-faceted political interests of the Palestinian Authority (PA), the Israeli state and the international donor community, Palestinian refugees, and their education, are at once highly visible and invisible. This article therefore seeks to understand the educational motivations and perspectives of Palestinians living in refugee camps. Drawing upon a qualitative study in the West Bank and utilising multiple, interrelated theoretical concepts, proposed by Galtung (1969), Freire (1972) and Bourdieu and Passeron (1990), the article argues that structural violence diminishes the collective, emancipatory importance attributed to education by those who live under oppression. In occupied Palestine, after 1948, motivation for education was tied to liberation and against oppression, and was valued as part of a national, collective liberation project. As the nature of Israeli occupation and control over education have shifted from predominantly physical to structural, this has led to a depoliticisation of the meaning of education, and a decollectivisation, and has been replaced by an individualised, instrumental, skills-oriented, successful and compensatory education for the impoverished and oppressive living conditions of the Palestinian

\footnotetext{
${ }^{1}$ To cite this article: Tejendra Pherali \& Ellen Turner (2017): Meanings of education under occupation: the shifting motivations for education in Palestinian refugee camps in the West Bank, British Journal of Sociology of Education, DOI: 10.1080/01425692.2017.1375400
} 
population. Youth now see education less as tied to liberation and more as a vehicle of individual material improvement. In this process, the poor material conditions and structural violence are complicit in instrumentalisation of education. Building upon these findings, we propose a new analytical framework for understanding the interrelationship between education, violence and struggle for social and political transformation in conflict-affected societies.

Firstly, we provide a brief contextual analysis of Palestinian refugee education drawing upon theoretical literature in the subfield of education and conflict. Secondly, we discuss our theoretical framework, building upon the concepts of structural and symbolic violence and education for liberation. Then, we provide an outline of our methodological approach, followed by a discussion of our findings, which leads to a new framework for studying sociology of education in conflict-affected and fragile contexts.

\section{Educational provision for Palestinian refugees}

The creation of the state of Israel in 1948, or nakba (catastrophe) for the Palestinians, was accompanied by extensive violence: widespread confiscation of land, and mass killings, lead-ing to forced exile of over 700,000 people, around two-thirds of the Palestinian population. Today there are 762,288 Palestinian refugees living in the West Bank out of an estimated population of 2.4 million, and there are over four million refugees living in refugee camps in Gaza, Syria, Jordan and Lebanon (UNRWA 2016). Historically, Palestinians have never formally had authority over their own education, reflecting their lack of political self-determination (Asaad 2000), and education has been forced to develop under ongoing challenges from external forces (Silwadi and Mayo 2014). Following the establishment of the state of Israel, education was primarily administered through Jordan and Egypt for the West Bank and Gaza respectively. Although 'culturally relevant', the Jordanian and Egyptian curricula were not 'nationally relevant' for Palestinians and did not meet their needs (Assaf 1997, 53). It has also been argued that they were designed to 'weaken Palestinianism' in favour of the provider government's national goals (Abu Lughod 1973, 97).

\section{Education as victim and perpetrator}

Despite some recognition that education can play a contested role in production and perpetuation of violent conflict, education policies and programmes in conflict-affected contexts are largely underpinned by the idea that education is a victim of conflict. Whilst the education sector suffers targeted attacks from both rebel groups and state authorities (GCPEA 2014), an overemphasis on the notion of victimhood tends to undermine the need for conflict-sensitive reforms within the education sector. It does little to engage with underlying processes of education systems that problematically interact with the causes and dynamics of conflict. The focus is rather on the narratives about widespread violence on teachers, students and physical infrastructure (GCPEA 2014; Machel 1996; Save the Children 2013; Sommers 2002) in order to advocate for protection and continuation of the existing pro- vision (INEE 2010; Sinclair 2002; Retamal and Aedo-Richmond 1998). In the West Bank, the first and second intifadas, or uprisings, saw occupation of schools by the Israeli military and high levels of direct violence against schools and educational communities including students, teachers and parents (Affouneh 2007; UNICEF 2004 as quoted in Akesson 2014). Some have argued that education was in fact targeted as a measure of collective punishment for Palestinians during the intifada years (Affouneh 2007; Alzaroo and Hunt 2003; Assaf 1997; Halstead and Affouneh 2006). The role of education in providing social and political consciousness and leading to act against injustices makes education vulnerable to violent attacks. The fact that Palestinian students resist Israeli military incursions makes them targets of direct violence.

The recognition that education has the potential to become a 'perpetrator' in contexts of conflict is a disturbing notion for educational practitioners. Education can perpetuate inequalities and fuel tensions through unequal access, biased curriculum, violent disciplining practices and the hidden curriculum (Lange 2012; Davies 2004; Harber 2004; Smith and Vaux 2003; Bush and Saltarelli 2000). As Bourdieu (1974, 32) 
explains, education can be 'one of the most effective means of perpetuating the existing social pattern' and, as such, can be a 'frighteningly powerful tool' for the perpetuation of marginalisation and disenfranchisement of particular groups. In the Palestinian context, the externally enforced education system until 1994 failed to serve the needs of the refugee population. Subsequently, the establishment of the first Palestinian curriculum has arguably been complicit in serving the political intentions of the PA rather than the needs of the communities (Brown 2001, 2003). The current education system promotes a version of nationalism through school textbooks, daily rituals and political symbols in schools that primarily cultivate loyalty to the ruling authority in the West Bank. The wider agenda of the Palestinian cause has been reduced to a discourse of statehood under current conditions of occupation and the PA's political goal, stemmed from the Oslo agreement (Moghli 2016). Hence, we argue that the formal education in the West Bank systematically represses opportunities to critically engage with the broader vision of liberation.

\section{Education for positive peace through resistance and liberation}

For Palestinians, education is the only political defence against the current state of routinised violence and Israeli occupation - the opportunity to learn contributes to aspirations for justice and freedom. This is concerned with the education-conflict relationship in which education is argued as a vehicle for collective resistance and liberation from systemic oppressions (Pherali 2016). In this regard, Galtung (1969) argues for 'positive peace', a condition which prevents direct violence as well as addressing its root causes, such as social injustices, poverty, exclusion, discrimination and marginalisation. In this perspective, schools can be seen as centres of resistance in the face of unjust social conditions and political structures (for example, Freire 1972; Giroux 1983a, 1983b; Pherali 2013). Through an improved system of governance and radical policy reforms, schools can promote 'positive peace' by enabling social transformations (Novelli 2016; Novelli and Smith 2011). For these purposes, Palestinians have continued to make education a national priority. In the West Bank, the struggle to access education in spite of numerous obstacles has turned the school into a symbol of resistance and has become a way in which Palestinians can resist the occupation in their everyday lives (Akesson 2014). A focus on strengthening national identity outside of the formal education provision in both the hidden curriculum of United Nations Relief and Works Agency (UNRWA) schools (Shabaneh 2012) and informally, through popular education that emerged during the intifada years (Fasheh 1990), can be evidenced as an act of resistance for peace with social justice.

\section{Violence, oppression and struggle: a conceptual framework}

The framework underpinning this analysis is founded in concepts of violence and the idea of liberatory education. It expounds that forms of violence can be recognised in interactions between individuals, groups and structures. Violence, as described by Galtung $(1969,168)$, is 'present when human beings are influenced so that their actual somatic and mental realizations are below their potential realizations'. Two fundamental tenets emerge here: firstly, there is the presence of an active, acting force carrying out the 'influencing'; and secondly, there is a process of reduction in 'potential realizations'. Personal violence is present when the 'acting force' is a human actor, and the potential realisations reduced are physical. Structural violence, however, is present when the potential realisations reduced pertain to opportunities and relations of power. Here, violence 'shows up as unequal power and consequently unequal life chances' $(1969,171)$. The acting force is not a human actor, but is built into, and perpetrated by, the structures that govern human lives.

The distinction between personal and structural violence is plainly a helpful one. It contributes to an understanding of the different ways in which human lives can be detrimentally influenced, and, in so doing, offers a platform from which to begin conceptualising liberation. However, Galtung's (1969, 171-172) suggestion that structural violence is unintended by human actors and has no human perpetrator locates the structure itself as an acting force, or perpetrator, in a mutually exclusive, opposing position to the human acting force of personal violence. This can be problematic because positioning humans and structure as 
oppositional forces may obscure interactions between the two. Oppression, as described by Freire (1972), offers an alternative conception of the relationship between 'humans' and 'structure as a perpetrator'. He posits that oppression is an 'unjust order' that serves the interest of an oppressive group. A system that facilitates manipulation or coercion on a marginalised group can therefore not be considered necessarily unintended. Structurally violent conditions may function as a tool in the wider context of the systemic oppression of vulnerable groups. Freirean notions of resistant or liberatory education might conceal more complex contradictions that speak for Du Bois' (2008) theorisation of 'double consciousness', a split personality of the oppressed who undergo internal conflict of two opposing perspectives about the world. In the case of African Americans, he notes:

It is a peculiar sensation, this double-consciousness, this sense of always looking at one's self through the eyes of others, of measuring one's soul by the tape of a world that looks on in amused contempt and pity. One ever feels his two-ness: an American, a Negro; two souls, two thoughts, two un-reconciled strivings; two warring ideals in one dark body whose dogged strength alone keeps it from being torn asunder. (Du Bois 2008)

Here, the oppressed group is forced to view themselves and the world around them through the lens of ongoing subjugation which denies their own self-conscious view of reality. Double consciousness emerges as the Palestinians are forced to embrace status quoist, hegemonic ideas that constantly cultivate individualistic, material aspirations, normalising the repressive political space, while their collective sense of liberatory aspirations and the romanticized 'Palestine' is deeply entrenched in the other side of the consciousness. The dilemma emerges from the inability to dwell upon either consciousness, the disconnection between and the failure to reconcile the two.

Speaking to this routinised dynamic, Bourdieu terms 'symbolic violence' as the processes by which injustices experienced can become internalised. The human mind may accept, without critique, environments within which they are situated, and fail to conceive of the possibility of liberation from these positions (Bourdieu and Passeron 1990; Bourdieu and Wacquant 2004). Education can become a tool in this process, as pedagogic action is 'the imposition of a cultural arbitrary by an arbitrary power' (Bourdieu and Passeron 1990, 5). Those 'receiving' this dominant cultural narrative may thus internalise it without critiquing its hegemonic position, the power of those disseminating this narrative, or their own identities as presented to them through this narrative.

\section{Methodology}

This article draws on a qualitative study that was carried out in two Palestinian refugee camps in the West Bank in the spring of 2015 . In both camps, $40 \%$ of the population is under the age of 14 , and the residents face major problems of overcrowding in their living arrangements and schools, a lack of open spaces and high levels of unemployment (25\% and 28\%) (UNRWA 2016).

The study primarily focused on the way in which the research participants negotiated their identities in relation to multiple forms of violence and the role of and meanings given to education in this context. To this end, research was conducted with 18 adults and 12 school pupils across two refugee camps (henceforth called 'Camp A' and 'Camp B'). Drawing methods were used with six boys and six girls across the adjoined boys' and girls' UNRWA basic schools in Camp A. The children were asked to draw a picture of their biggest dreams and to explain what it meant in their own words. This was to enable them to expand on the role education played in their imaginations, their subjectivities and their hopes for the future. The selection of these methods attempted to address some of the challenges inherent to research with children and to provide space for them to engage with creativity and nuance (van Blerk 2006; Eldén 2012). Furthermore, children's verbal accounts of their drawings were prioritised to try to avoid obscuring or decontextualising their meanings. Semi-structured interviews were conducted with adults representing various roles in order to understand the perspectives and contexts in which the learners constructed their educational identities, and to gain insight 
into generational differences. The adult participants consisted of six teachers, four parents, one school assistant, one UNRWA education supervisor and six young adults aged between 18 and 25 years. All participants were Palestinian and all apart from the school staff were registered refugees. There was gender parity across learners, teachers, parents and young adults, while the two extra educational staff were male.

The data were analysed to capture the phenomenon by 'grasping and formulating a thematic understanding' which 'is not a rule-bound process but a free act of "seeing" meaning' (van Manen 1998, 79). Meaning was found in both the events described and the 'cultural frames' that the participants drew on to make sense of these events (Miller and Glassner 2010, 137). Grounded in a social constructionist approach, data were not seen as representations of reality but 'displays of perspectives and moral forms' (Silverman 2011, 199). It became apparent, both in the process of data collection and in the analysis, that the interviews with adult participants played a central role in shaping the research findings. Relevant quotes from these interviews have been reported to evidence the shifting meanings of education that emerged in the data. Educational staff tended to be older participants who drew on close, personal knowledge of both the educational perspectives of their parents' generation and their students today. In this way, these participants fulfilled a rich, interpretive 'bridging' role between the first generation of Palestinian refugees and young refugees today, as well as drawing on their own experiences of violence and education. The cultural frames through which adults viewed young learners' educational subjectivities, and the moral forms they drew on, revealed much about the contexts in which their own meanings of education were formed. Clear differences were noted between these moral forms and those of the children themselves, highlighting interesting points of disjuncture and thus directing analytic questions towards contextual shifts.

Bryman's $(2008,554)$ 'framework strategy' was useful when plotting participants' responses against the key themes, which are represented graphically according to their age and experience. In order to do this, we examined the data carefully and plotted participants' expressions on a scale in terms of their deliberation on interconnection between education and collective freedom from oppression. The scale of interconnection also accounts for repetition of key words or phrases and the participants' emotions underpinned in the data. We then reflected on these holistically and negotiated our subjective interpretations to plot individual participants on the axes in Figure 2 (shown later).

\section{Education at the historical heart of Palestinian refugee identity: the education and liberation nexus}

\section{Meanings of education for the first generation of Palestinian refugees}

Palestinian educators, parents and young adults described, and reproduced in the act of describing, a strong, collective identity in their testimonies, and education was located at the heart of this identity production. Education was widely considered by many to be a fundamental aspect of life for Palestinian refugees, whose importance was assumed to be inherent and was connected to their political circumstances:

Education is the first component for Palestinians. Education is life for them. We don't have components for a state - therefore education is the first priority. (Mahmoud, male parent)

Many participants drew on the notion of 'education as life' for Palestinians, suggesting the attribution of cultural meaning which denotes that education is of fundamental importance. Education appears to hold discursive relevance as something that relates to the Palestinian identity. The notion of a shared identity, a shared struggle, and the central role of education, appeared to have emerged from the generation of Palestinian refugees who had experienced first-hand personal violence of expulsion in 1948:

This is a very important point, the concept of respecting education in the past. [...] In our age and in the past, you can say 60 years old and before, all of them respect the concept of education. They respect it fluently. Because, in the past, they say education, teacher, it is a holy thing. (Yusuf, male teacher)

Hassan, a male teacher, described the meanings of education learned from his parents: 
My mum and dad didn't enter schools, didn't know anything, died many years ago, and many other Palestinian families [were like] them. But when we were children they said to us 'your machine gun in life is your education. You must live in a good way in life, not like us. They said that Palestinians lose their houses, lose their country, so your machine gun in this life is sense, and only sense. If you can study, and study not as a person, [but] all Palestinians, you can have a good life. [...] But when you are people who can't write or read, or haven't education, you will lose again.

A collective sense of loss that shapes a shared identity is vividly described here. Khalidi $(1997,194)$ explains that this historical moment of 'defeat, dispossession, and exile' was a significant moment of collective identity formation, or affirmation, for Palestinian refugees. This shared identity opened the space for education to be embodied with a collective meaning. Despite not being formally educated themselves, Hassan's parents found a hope for the future in education of the new generation, and adult Palestinian refugees today continue to engage in traditionally held concepts of education, showing that these meanings have developed strong cultural significance.

For adult participants, the importance of education was also seen in its role in facilitating resistance for Palestinian liberation. The frequency and ease with which participants drew on the notion of education as liberation, and the fact that its significance was assumed, suggests that it holds strong cultural meanings:

For the country, we are an occupied country and in order to have our liberation we need to be educated. (Hanan, female teacher)

In Palestine the idea is, like, Palestine cannot be liberated unless we have got education. So that we have to be well educated, to study in order to become a good nation, to liberate Palestine. And this idea is mostly, more in the refugee camps. Like, refugees think that they can't be ... unless they are educated. (Tarek, male young adult)

Here, Hanan refers to the discursively located meanings attributed to education without explaining them, suggesting deeply held and widely shared significance in Palestinian refugee society. Interestingly, Tarek as a young adult is of a generation below many of the adults who espoused these meanings. The fact that his testimony is phrased more as an interpretation or explanation of the cultural narrative speaks both to the power of its cultural currency and also a certain distancing.

Interconnected to the idea of education for liberation was the notion of education as resistance. Through the culturally significant metaphor of education as a 'machine gun', or an empowering tool, several adult participants saw that education had the potential to contribute actively to resistance against the occupation:

[Education is] important because of our circumstances. You know, our situation under occupation. So, the certificate is a very important thing here, because of our situation. [...] Our certificate is our weapon. (Fatima, female teacher) under occupation, militaries oppress people. Education is a weapon [against oppression] for Palestinians. (Mahmoud, male parent)

Education is perceived simultaneously as the hope for achieving a better life in the future and a way of strengthening the resistance of the Palestinian refugee community. As Figure 1 demonstrates, for adult participants the idea of education and Palestinian liberation in the face of direct violence appeared to have a symbiotic relationship. The presence of a strong, shared commitment to Palestinian liberation and resistance, and the shared belief that education could play a role in this struggle, led to reinforced motivation for education. The formation of collective ownership over these meanings appears to speak to the deep sense of loss which was experienced during the Nakba. Education, in the face of material loss such as home and country, symbolised something that could not be taken away (Fronk, Huntington, and Chadwick 1999; Alzaroo and Hunt 2003). 


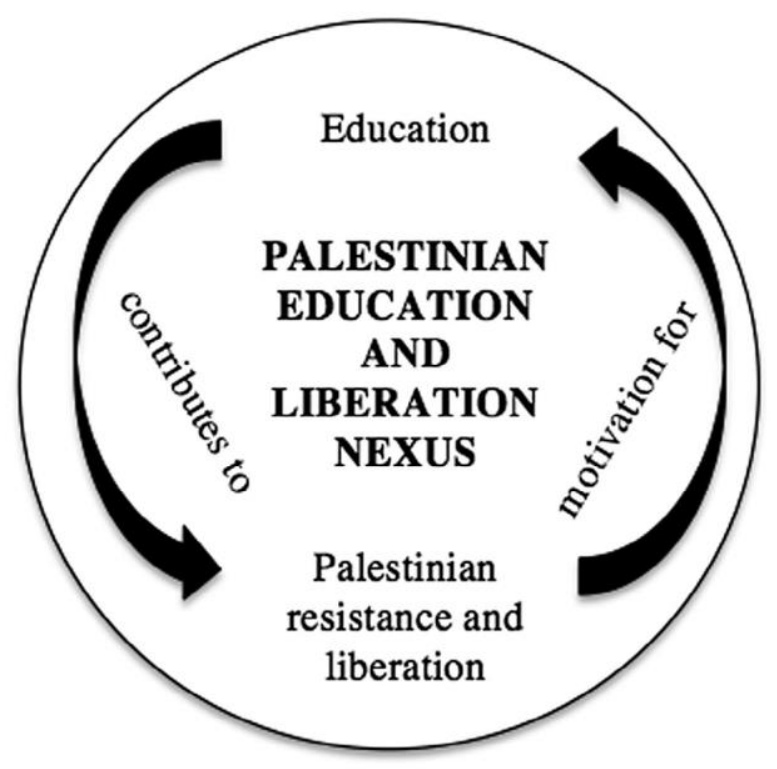

Figure 1. Palestinian education and liberation nexus.

\section{Education during the intifada years (1987-1991 and 2000-2005)}

When reflecting on the intifada years, several adult participants discussed the violence they experienced, and education was presented as a key site of this violence and resistance. As widely reported in education and conflict literature (Pherali 2016; GCPEA 2014; UNESCO

2011), schools in Palestine were also made both victim of violence and sites of resistance to this same violence:

The Israeli soldiers sometimes followed school children, and fired on them when they made demonstrations. In [my] school a student was killed by Israeli soldiers, inside the school. And sometimes schools were closed by the military forces [...] Thousands of Palestinian teachers lost their jobs when they talked about freedom. (Abdalkarim, male education supervisor)

When I was in school there was the second intifada. People were thinking a lot about occupation. Like, when I was in the UNRWA school I had no school for 2 months, or 3 months. There was curfew. Every other day we had curfew. So people kept thinking of occupation, the issue was there, everywhere. [...] when we had someone killed by the Israelis, we used to strike and not go to school. We have this, like, history from the past. When people, in the first intifada, you know, Israel was controlling the schools and everything here. So, people ... when they have something, they had a strike against the Israelis. (Issa, male young adult)

Violence on schools can be both active, as an attempt to 'destroy the machine itself', and passive, to 'prevent the machine from functioning' (Galtung 1969, 175). The descriptions of active destruction included schools being physically damaged and taken over by military forces and use of weapons against staff and students which adversely impacted on the quality of education. Hassan described the daily journey of teachers living outside the city checkpoints to reach their schools:

As a teacher, for three years we wake up at 3 o'clock in the morning. And we go out ... there isn't streets ... The streets are damaged and cut by the bulldozers. There are Israeli soldiers ... not on one side, [so you can] move around them. But everywhere. And we move through the mountains. We spend more than two hours. Sometimes we must hide ... Sometimes they shoot at the people. It's raining, it's very cold. The women, you see them, shoes have been damaged, their umbrella ... the wind took it. We came [to school] very tired. Very tired. [...] Sometimes I hear and I see many people have been injured or killed. You must run or you must disappear. I think I can't say that I did my job well and for my students. If you hear someone killed near you, how can you teach or learn well? You find yourself in a bad condition. So I think the result is that the students will do badly.

As emphasised, violence is directly and indirectly destructive to both the individual and to education. The precariousness of everyday life and physiological vulnerability debilitates the quality of learning and teachers' and students' general well-being. A sense of collectiv- ism in struggle was apparent as the participant frequently referred to 'we', rather than to ' $I$ '. Despite schools and their constituencies being tactical targets, 
teachers continued to show commitment for teaching. Hassan's vivid language, fragmented sentences and easy move into the present tense point to his deep commitment at present and hint at the power of its legacy. In the face of physical attacks, motivation for both education and Palestinian liber- ation seemed to increase. The role of education as victim and the simultaneous recognition of its importance seemed to be inextricably connected:

People looked at education in two spheres: The way that education was damaged and the impor- tance of education. In spite of these obstacles people tried to go on and continue education because it is the way of liberation. (Abdalkarim, male education supervisor)

It therefore appeared that during the intifada years, and in the light of the violence to which it was subjected, there was a heightened awareness of the value of education. According to some participants, the shared historical meanings attributed to education seemed to heighten during this period.

Hassan: We had two times the uprising, the intifada. And during that, there isn't any work, there are many problems for people. So sometimes you find that education is very good, sometimes it declines.

Interviewer: And so you think it declines during the intifada years?

Hassan: For the results of education, the achievements of the students ... Yeah.

Interviewer: But do you think the importance of education in these years is more, or less, the same? As the not-intifada years.

Hassan: Higher, higher. It's higher.

Hassan, male teacher

The very visible and tangible damage carried out to education meant that it served as a threat to the oppressing force by contributing to the struggle for resistance and liberation. As suggested in Hassan's statement, it appeared across the participants that those adults who had lived through the personal violence of the intifada years expressed the most consistent and strongest attachment to the education and liberation nexus. This is depicted in Figure 2.

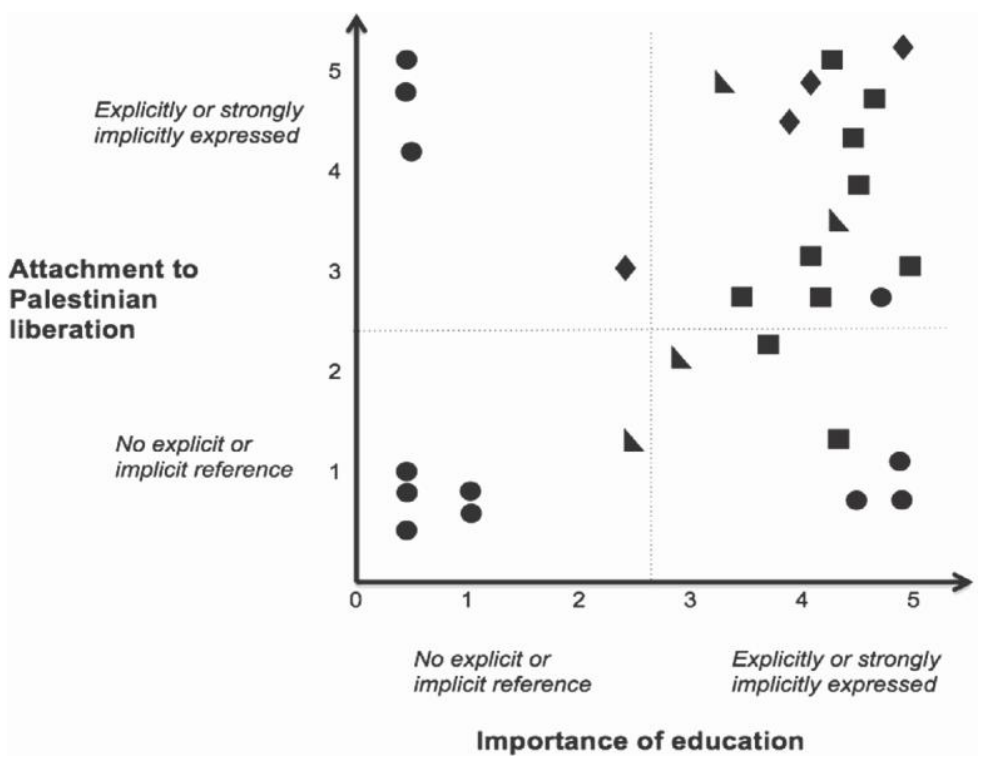

Key:

Belonging to age group $>34$ - older than age of 10 during first and second intifada, and Israeli occupation (pre-1994)

Belonging to age group $>20$ - older than age of 10 during the second intifada

Belonging to age group $<20$ - younger than the age of 10 during the second intifada (exact age unknown) Belonging to age group $<15$ - too young to have lived through the second intifada 
Figure 2. relationship between education and Palestinian liberation across age groups.

The suggested increase in educational motivation during the intifada years can be linked to the potential for education to contribute to resistance and liberation during this time. In the light of violence against schools, forms of popular and informal education emerged (Asaad 2000, 392; Silwadi and Mayo 2014, 82) and continued illicitly when they were made illegal (Fasheh 1990; Assaf 1997, 54). This form of critical, grass-roots education can play a role in the struggle for liberation from oppression as it emerges directly from the Palestinians themselves and can thus be put to their own ends (Freire 1972). Furthermore, the act of attending school in itself can also become an act of resistance, as Akesson (2014) also suggests is occurring during incidences of personal violence today. Therefore, some- what paradoxically, when institutional education faced violent attacks, informal education served as a space to nurture the Palestinian struggle both symbolically and practically. As Mahshi and Bush $(1989,474)$ note, 'the intifada resulted in a loss of literacy and numeracy skills, but a growth in self-reliance and self-esteem'.

In the context of personal violence, the self-consciousness as oppressed becomes particularly acute. Ali, a male teacher, described:

If you see soldiers in the street, shooting at people, killing people, they wake up. [...] Those who burn our

children alive are inhuman. And we must resist.

Here, the perpetrator and the violent nature of the relationship was clearly visible, definable and widely recognised. Galtung $(1969,171)$ explains that 'violence with a clear subject- object relation is manifest because it is visible as action'. To state plainly, 'personal violence shows' $(1969,173)$. During the intifada years, the location of the perpetrator, and of the self as victim, became visible and tangible. The explicit need to fight against this oppression, shown in the expression that 'we must resist', is essentially connected to oppressor's visibility. Hence, motivation for Palestinian liberation increases because the oppressor can be clearly identified, located and fought against. Motivation for education also increases as it can play a fundamental role in achieving freedom.

\section{Shifting motivations: education in the context of structural violence today}

\section{Decreasing motivation for education as liberation}

The educational landscape in Palestine today appears to be shifting from its longstanding interconnection with motivation for Palestinian liberation. Motivations for education among young participants seemed to be much weaker than among the older generations, and many adult interviewees lamented at length that children were losing interest in school and saw less value in education. Participants frequently perceived this trend was related to the structural violence of life under occupation.

Our point of view, according to teaching, is depending on the Occupation itself. If the Occupation was over it would become better, because psychologically and their attendance towards teaching will change. For example, take the residence that they live in. In camps, here at [Camp A], in [Camp B], look at the people. Look at the crowded houses. It also affects their mind and their desire for learning. (Yusuf, male teacher)

His life is damaged because his thoughts change a lot. He needs psychological treatment for this situation. Even in his dreams he dreams of the situation. So, he is in bad conditions. Our children. So, the Occupation is the main reason for the students not studying. (Fadi, male school assistant)

As shown in these examples, issues such as overcrowding, poverty, poor health and imprisonment of members of the community were widely felt to have had a detrimental impact on education. Poor economic conditions and subsequent high unemployment was perceived to be the most significant contributor to loss of educational motivation:

They don't care [about] learning. In the past they liked to learn, but nowadays they see that graduates do not have jobs. So they say that teaching is not for any use, it does not make money 
... does not make anything for people. (Fatima, female teacher)

In the old days, children used to come to school and they want to learn. They had a kind of impulse to learn. These days, because of very bad economic situation, they think it's crazy to come to learn. [...] Nowadays education does not give people the money or the salary they wish to have. (Ali, male teacher)

While many adult participants expressed the view that the poor economic situation led children to lose educational motivation, this also suggests the motivations for valuing edu-cation are changing. Comparisons between the past, when education was perceived as having inherent value, and today where it is valued for economic potential, were made by Issa, a young male adult:

Before, people were mostly educated just for education. If you compare our generation to my father's or my mother's generation, how education affects then ... mostly they love education. They can see or remember things from their curriculum, unlike our generation today. [...] Today, just to get employment.

The concept of Palestinian liberation, or the belief that education can contribute to this struggle, is losing currency with young people. As young people are principally concerned with the difficulty they face in securing their livelihoods, political ambitions appear to be declining. Consequently, the young generation's motivation for education is also shifting towards marketised liberal aspirations. Education, under the structural violence of poverty and high unemployment, is unable to fulfil these aspirations, and thus motivation for education appears to be declining.

The data drawn from children's drawings corroborates these findings. When asked to draw their dreams for the future, the young participants most frequently associated their aspirations with material well-being and individual success (Figures 3 and 4).

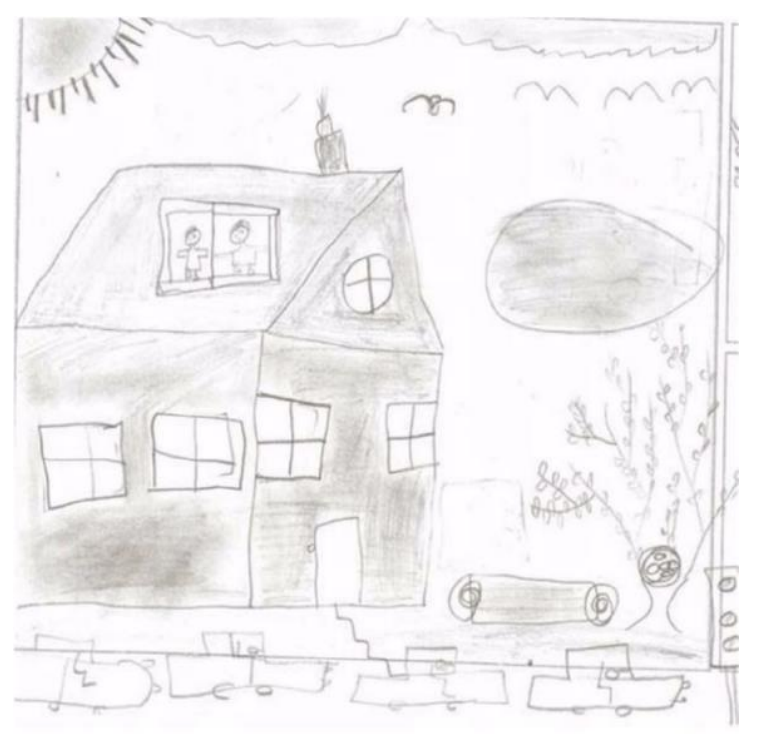

He drew a house, with trees. And he owns a lot of cars and a pool. He plans to be a rich man! Mohamed

Figure 3. Mohamed's drawing. 


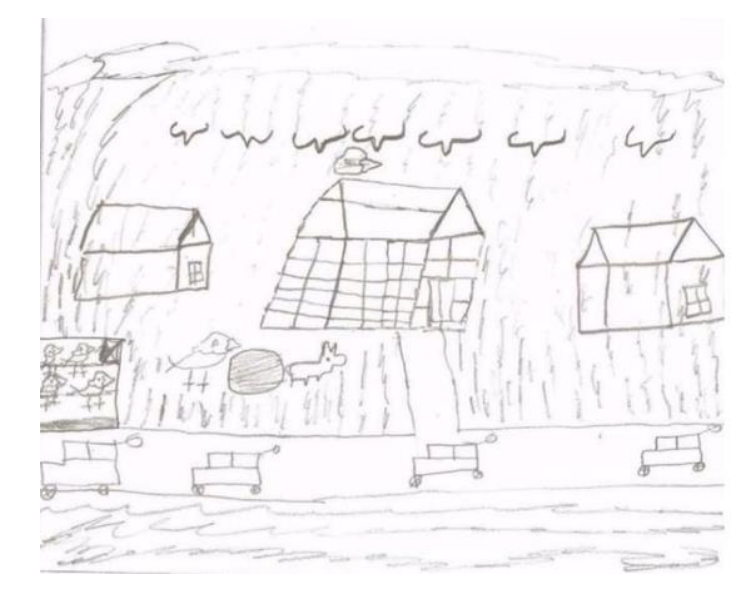

He dreams that he has a farm and in the farm, he has houses to live in.

He hopes to have animals in his garden. Hakim

Figure 4. Hakim's drawing.

These drawings, and the translated explanations, show that children dream of wealth and large living spaces in nature, revealing, perhaps, the aspects of life in refugee camps that they find most difficult. These dreams speak to the cramped, overcrowded living conditions, poverty and restricted mobility of their realities. The adults' perceptions that children are not primarily motivated by education, and that the material realities of life under occupation are difficult for them, thus appear to be supported.

Additionally, some participants also emphasised that children were becoming less aware of their history, of their situation as oppressed and less motivated by the idea of collective national identity as Palestinians, as prevalent in instrumentalised, ahistoricised and apolitical educational experiences globally that define educational success as employability in the job market:

These days, the students are not ... they don't have the revolutionary mood that they had before. (Issa, young male adult)

Ali, a male teacher, reflected:

Maybe [children] are in a kind of coma. [...] When I was their age, at an UNRWA school, you ask any student where they came from and they would tell you from Haifa, from Yafo, from Akko. Here, go to any class and ask where they are from. He will tell you from [Camp A]. He doesn't know where his parents, grandparents came from. So he is lost. He thinks that [Camp A] is his homeland.

While some participants did engage with the concept of Palestinian liberation and with education, these aspirations were expressed rather sporadically and often disconnected. Young participants appeared to find new ways to personalise and find meanings in these concepts (Figures 5 and 6). 


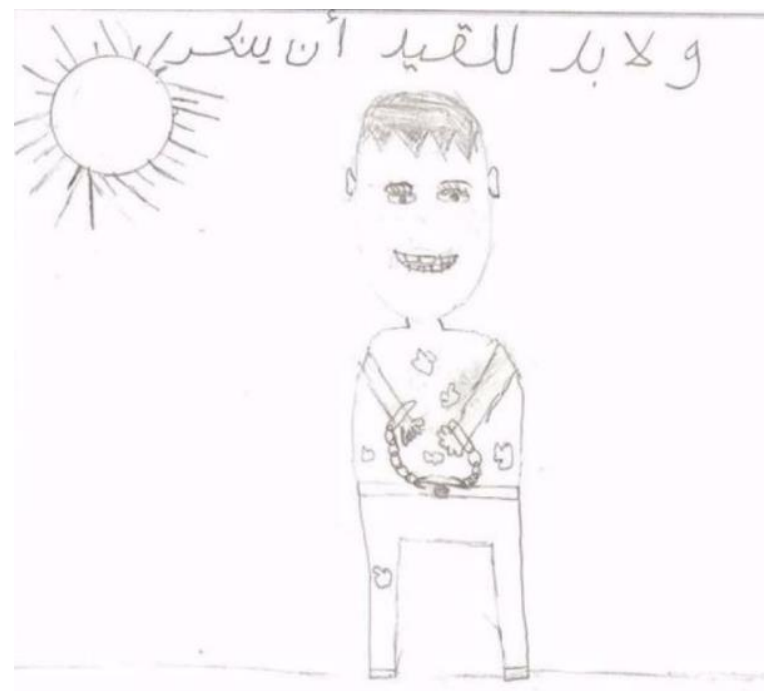

The men who are in prison, one day they will be freed.

For liberation in the future. He would like to liberate from the occupation.

Saeed

Figure 5. Saeed's drawing.

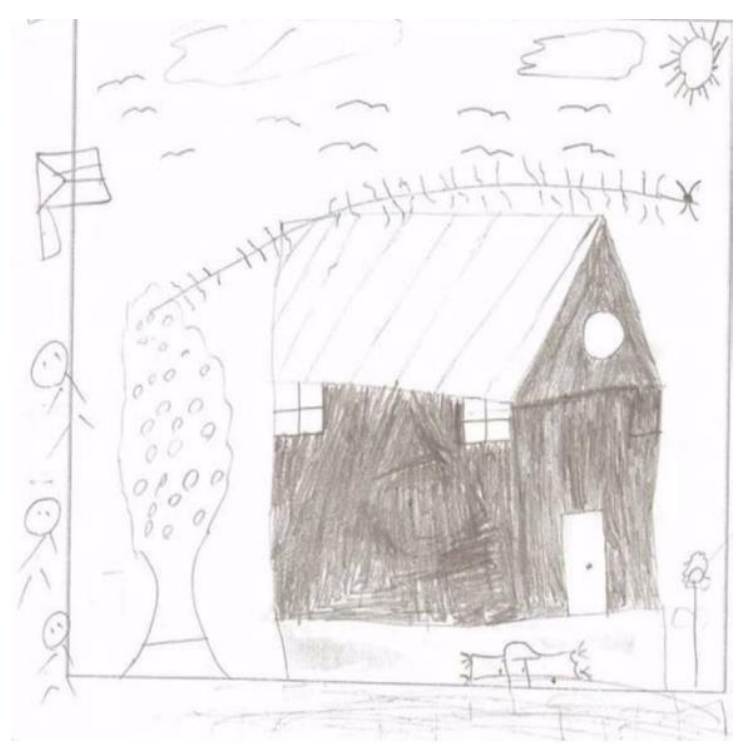

He dreams that his home is next to the sea, and there are some trees, the sun, and he hopes that this house will be in Jaffa. Not here at [Camp A]. Haitham

Figure 6. Haitham's drawing.

Haitham's drawing portrays a visualisation of his lost ancestral home. The Palestinian flag alongside a group of refugees returning to their ancestral homes is powerfully depicted to indicate the wider, national liberation. Saeed's drawing exposes experiential dimensions of imprisonment and the desire to gain both personal and collective freedom from oppression. Both boys appear to project themselves into an imaginary future, with no notion of education or any other means by which this dream of liberation could be realised. 
The focus seems to be on personal rather than collective dreams. Girls, however, displayed a strong connection to education (Figures 7 and 8 ).

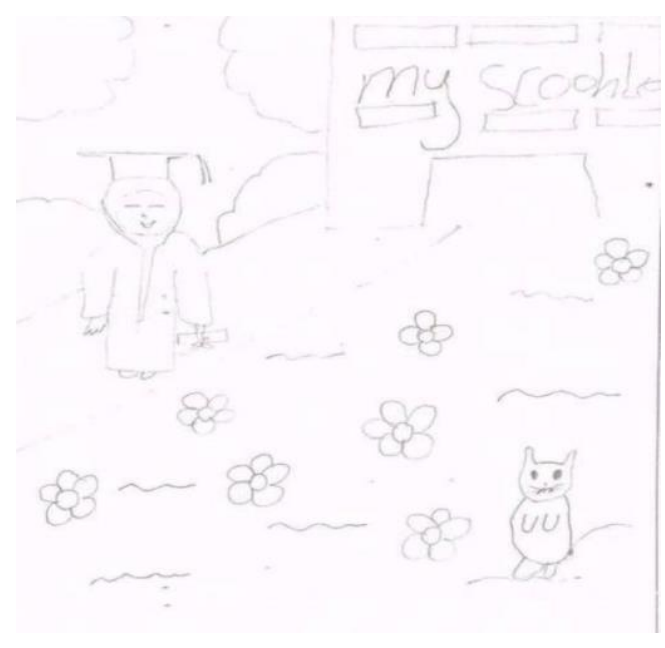

My dream in the future is to finish school and to continue studies. It is not necessary to work. Hala

Figure 7. Hala's drawing.

Recognition for academic success, achieving a responsible position and becoming a teacher emerged as key themes in girls' drawings; however, these were never directly related to a collective Palestinian liberation. Overall, therefore, children were engaging with the concepts of Palestinian liberation and education in infrequent and incoherent ways, and were manifesting these concepts to reflect their personal aspirations. Most significantly, the explicit pathway of education to Palestinian liberation was absent in children's drawings.

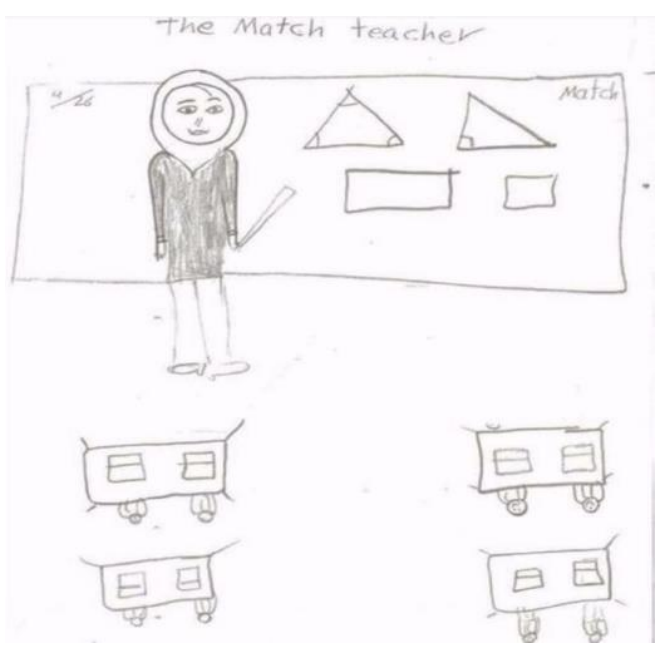

Maths teacher... because to help the girls and students. This is my biggest dream. Sundus

Figure 8. Sundus' drawing. 


\section{Education as a perpetrator of symbolic violence}

No longer depicted as a victim of physical violence, education can be seen as becoming a perpetrator of its own reduced significance through its co-option in the forms of structural inequalities (Pherali 2016; Novelli and Lopes Cardozo 2008). The violence is carried out both against education in itself and through it against teachers and students. The curriculum was described as highly inadequate and unrelated to the lives of students and Palestinians in general:

In the syllabus, nothing about the Palestinian people is mentioned. I teach [them] about Japan, I teach [them] about the methods and manners of food in China ... Nothing about Palestine. If you open any book, the subject itself doesn't relate to [them]. These subjects are not preferable for the students; they do not meet their needs. So, for example, it's less ... the child likes the things that he wants, likes the things that fills his desire. (Yusuf, male teacher)

Yusuf 's description depicts a lacuna in the Palestinian curriculum: a space in which Palestinian students can find themselves and relate to the world they study about. Most importantly, participants lamented the absence of Palestinian refugee history, and the curricular approach that systematically erased the memory of Palestinian roots through an atemporal and inherently incomplete depiction of their refugee status:

The subject History, mostly it's incorrect. [...] Like, we are refugees, we came from Haifa, and in our curriculum, they tell us that this is not our land. We have in our mind the Oslo map. Like for Palestine, we know just the West Bank and Gaza. What happened to the Arab cities on the other side? (Amal, young female adult)

Participants felt that their personal histories were not only omitted, but actively denied. This process significantly decreases their 'mental potentialities' in making sense of their positioning. A systematic deflection of everyday realities in formal education stupefies the learners by routinising the unreal world and thereby reducing their human agency to challenge the structures:

If you lose your hand, you can still go home. If you lose your sight, you can still go home to England. But if you lose your memory, you are lost. Right? If you lose your memory ... (Ali, male teacher)

As Ali expresses, for many participants there was a strong belief that knowledge of history is essential for collective identity and Palestinian liberation. Education, through curricular omissions, is therefore implicated at the heart of a loss of 'memory' and in reducing its relevance to learners' lives.

Several participants felt that these omissions were deliberate attempts to reduce Palestinian consciousness, identity and criticality. The Palestinian curriculum featured, for some participants, as a key part of the control of Palestinians under occupation:

Ali (male teacher): Let me say our character here in Palestine is something...deformed.

We are not Palestinians, we are not Jews, we are not Arabs, we are not

Muslims, we are something like beggars waiting for food from others. Interviewer:

And you see this in the education system as well?

Ali: Right. They got this through education and NGOs. [...] They take a bunch of supervisors from Ministry of Education, they take them to Europe for 20 or 30 days, they teach them

'do this, do that, don't do this, do that, and that' and that's it.

It is revealed that for some participants education was being used as a perpetrator of structural violence. By omitting to teach Palestinian refugees about their history, and by attempting to reduce Palestinian collective consciousness and identity, education is perceived to be contributing to the structural subjugation. This also appeared to be supported through the pedagogy, which several participants felt was designed to reduce criticality and agency:

They teach them how to be cowards. Somebody would shoot you and you would do nothing. (Issa, young male adult)

The education system here just gives the students some information which makes him like a robot. (Tarek, young male adult)

This perspective extended to informal education provided through externally funded community centres. Ali, a male teacher, explained that the message was: 
We have to cry, because we have settlements. Just cry, cry. Don't do anything ... just cry.

Pedagogically, the participants felt that learning through 'memorization' of information geared students to an uncritical acceptance of information which they termed 'indoctrination'. This reflects what Freire labels as 'banking model of education', which 'serves the interests of oppression', presenting reality as 'motionless, static, compartmentalized and predictable' (1972, 64-57). Education for young Palestinian refugees today therefore appears to encourage ahistorical learning, and to pedagogically guide them towards acceptance of the status quo and indoctrinates into a belief that their social and political context is a static reality. Thus education, far from being a means to freedom, is complicit in perpetrating symbolic violence on learners.

\section{Decreased consciousness about the oppressor}

There was an emergent confusion as to who is responsible for these myriad forms of structural violence. In the context of structural violence, the location of the perpetrator and tangibility of violence can both become obscured. At times, teachers expressed frustration at the students themselves for their lack of motivation:

The pupils, they don't help us. They don't care about learning. [...] They don't want to learn. (Fatima, female teacher)

[In the past] it was better. The quality of students was better. The students were better to deal with you. They wanted to study. But here, they say why do we learn English? [...] They don't care. Students don't care. (Nashwa, female teacher)

With regards to education, very few participants discussed who they believed was responsible for the curricular shortcomings. Some believed that the curriculum remained indirectly controlled by the Israeli government and international donors through the administrative countenance of the PA:

The Palestinian Authority started to change the curriculum, and to join with the Palestinian traditions, or goals. But they were controlled with ... the agreements with Israel. [...] In the new curriculum [there is something about] how to build the Palestinian character ... but it is controlled, or judged, by an agreement. Not as we hope. In an indirect way, the [Israelis] did this. They put laws and in these limited laws you can put your curriculum. (Abdalkarim, male education supervisor)

We don't have an identity for our philosophy in education. Before the PA, we used to have it unwritten. It was something that we all agreed on. It wasn't written, but we knew it and did it. Why? Because we were under occupation and our aim and our goal was to fight and resist the occupation. Now we have the PA and what has the PA done? It has made everything faceless. No character. We are under occupation and we have Palestinians ruling us. And we are lost between the occupation and our representatives here. (Ali, male teacher)

In this way, the PA was perceived to be complicit in perpetuating Israeli occupation thorough public sectors including education, a development which has politically disillusioned many Palestinians. The PA, supposedly representing the oppressed Palestinians, fails to liberate itself from the 'oppressors housed within' and thus it remains in power, 'still embodying that ambiguity imposed on them by the situation of oppression' (Freire 1972,121). This further complicates the idea of identifiable oppressor outside and distorts the collective Palestinian identity, consequently leading to a decline of motivation for resistance and liberation.

As expressed in Figure 9, this can be considered a process of symbolic violence in which the oppressed fail to conceive of or fight for their liberation. 


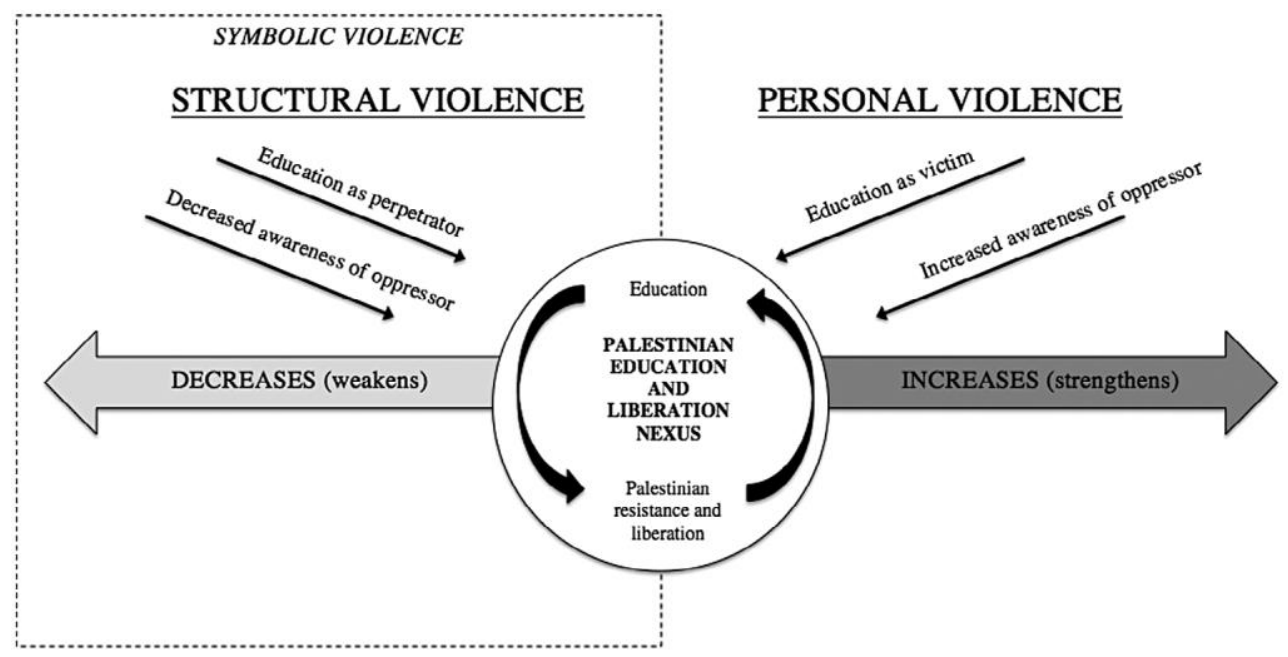

Figure 9. Education, violence and liberation: a new theoretical framework.

While 'the object of personal violence perceives the violence [...] the object of structural violence may be persuaded not to perceive this at all' (Galtung 1969, 173). The 'persuasion' or manipulation of groups to adapt to their situations of structural violence is fundamental to the purposes of oppression. For Freire $(1972,63)$, 'the purposes of the oppressors [rest] on how well men fit the world the oppressors have created, and how little they question it'. The less visible and tangible the oppressor becomes, the less one can be sure of the existence of violence and where to direct one's frustration. Furthermore, children appear to be focussing more on their personal liberation from the structurally violent effects of the occupation, rather than questioning the oppression itself collectively. This lack of collective engagement represents a highly significant shift away from the recognition of their shared position as excluded or oppressed to individuality, thereby weakening the project of collective liberation. Bourdieu and Passeron (1990, 41-42) argues that exclusion has 'perhaps the most symbolic force when it assumes the guise of self-exclusion'. The symbolic violence seen in young people turning away from collective liberation, and education as a means to this process, can be seen as a particularly significant and far-reaching effect of structural oppression.

\section{Conclusion: towards a new framework of educational analysis in conflict- affected contexts}

In this article we have explored educational meanings and motivations for Palestinian refugees in the West Bank. It emerged that the meaning of education which developed during the shared experience of expulsion in 1948 was inextricably connected to a strong, collective Palestinian identity. More importantly, the relationship between Palestinian liberation and education was conceived of as mutually reinforcing. This nexus grew stronger in its significance during the periods of widespread 'personal violence' but seems to be declining as the violence now operates through social, political and economic structures (Galtung 1969).

Education in the West Bank today strives to construct a Palestinian identity which is manipulated by the oppressor's worldview and denies Palestinians the ability 'to attain self-conscious' humanity (Du Bois 2008). Palestinians can neither secure dignified self in the present political situation nor fully embrace the status of apolitical, materialistic citizenry that is being promoted through formal education. The continued resistance is part of manifestation of this double consciousness to the external world in which Palestinians are 'pre-occupied with answering and resolving the racialisation or otherisation' (Bazian 2013) of existing oppressive structures. The ahistoric and apolitical portrayal of Palestinian identity, as the hegemonic narratives often represent, makes it 'impossible to a 
negation' which is entrenched in the normalisation of occupied lives. The idea of the Palestinian state as 'a problem' is located in the colonial repertoire and externally driven programmes of educating Palestinians for peace. In this process, the purpose is essentially to address the oppressor's difficulty to rule rather than to emancipate the oppressed. Hence, as Du Bois (2008) notes, as in the case of African American response to brutal racial domination, Palestinian response is also articulated in three main forms:

- a feeling of revolt and revenge; an attempt to adjust all thought and action to the will of greater group; or finally, a determined effort at self-realization and self-development despite environ opinion. (Du Bois 2008)

Bourdieu and Passeron's (1990) concepts of symbolic violence informed our theoretical analysis to show that oppressed people can internalise narratives of exclusion, consequently making them disillusioned about their positions as oppressed, thereby perpetuating double consciousness.

Both the curriculum and pedagogy contributed to reduce young refugees' awareness of their historical and present-day political reality, and failed to develop skills of criticality and self-determination. This kind of educational approach diminishes political agency as 'if allowed to develop on its own, it would bring into focus a historical continuity, indigenous knowledge and resourcefulness that may possibly lead to the disruption of the colonial paradigm and breaking the hold of double consciousness' (Bazian 2013).

Synthesising aspects of Galtung's concept of structural violence and Freire's concept of oppression, we developed a framework of analysis that revealed how structural violence on both human actors and education can contribute to a decreased significance of the nexus between education and liberation. Additionally, we see education for critical consciousness as a means to reject internalised forms of symbolic violence and to claim human dignity, freedom and justice. Hence, the framework allows us to critically engage with liberal reforms in education that essentially reproduce unequal socio-political structures and contribute to pacification of struggles against social injustices. This also lends us to appreciate the political economy of educational processes (e.g. education policies, curriculum, educational financing, teacher recruitment and redeployment, pedagogy, assessment and certification) in which national political elites, international organisations and other forces are complicit in perpetuating geopolitical interests and suppress social justice movements that may emerge through critical education. This framework offers a critical lens to the existing advocacy programmes such as education in emergencies (INEE 2010), protection of education from violent attacks (GCPEA 2014) and even the more progressive and social justice framework of 4Rs (Redistribution, Representation, Recognition and Reconciliation) (Novelli 2016) in the context of complex, protracted conflict. The cessation of personal violence, as important as it is, does not necessarily lead to justice; it can rather be transformed into structural violence that weakens the struggle for grassroots empowerment. The education and peace- building models such as the 4Rs can do little in the absence of critical consciousness and transformative political action from the grassroots. Our analytical framework provides a new perspective to critique less obvious forms of oppression that are more destructive and inhibitive to the struggle for liberation and social transformation.

\section{Note}

1. The term 'Nakba' will henceforth be used to refer to the events of this time. In line with a constructionist epistemology, this study acknowledges that meaning is found in the ways in which humans experience reality and reflect on this experience. The term 'Nakba' is therefore used for its particular resonance with participants.

\section{References}

Abu Lughod, I. 1973. "Educating a Community in Exile: The Palestinian Experience." Journal of

Palestine Studies 2 (3): 94-111. 
Affouneh, S. J. 2007. "How Sustained Conflict Makes Moral Education Impossible: Some Observations from Palestine." Journal of Moral Education 36 (3): 343-356.

Akesson, B. 2014. "School as a Place of Violence and Hope: Tensions of Education for Children and Families in PostIntifada Palestine." International Journal of Educational Development 41: 192-199. Alzaroo, S., and G. L. Hunt. 2003.

"Education in the Context of Conflict and Instability: The Palestinian Case." Social and Policy Administration 37 (2): 165180.

Apple, M. W. 1990. Ideology and Curriculum. New York, NY: Routledge.

Asaad, D. 2000. "Palestinian Educational Philosophy between past and Present." Studies in Philosophy and Education 19: 387-403.

Assaf, S. 1997. "Educational Disruption and Recovery in Palestine." In Educational Destruction and Reconstruction in Disrupted Societies, edited by S. Tawil, 51-61. Geneva: UNESCO.

Bazian, H. 2013. "The Souls of Muslim Folks." Al-jazeera. https://www.aljazeera.com/indepth/ opinion/2013/10/souls-muslim-folk-20131029124336354563.html

van Blerk, L. 2006. "Working with Children in Development." In Doing Development Research, edited by V. Desai and R. Potter, 52-61. London, UK: SAGE.

Bourdieu, P. 1974. "The School as a Conservative Force: Scholastic and Cultural Inequalities." In Contemporary Research in the Sociology of Education, edited by J. Eggleston, 32-46. London, UK: Methuen.

Bourdieu, P., and J. C. Passeron. 1990. Reproduction in Education, Society and Culture. 2nd ed. London, UK: SAGE.

Bourdieu, P., and L. Wacquant. 2004. "Symbolic Violence." In Violence in War and Peace: An Anthology, edited by N. Scheper-Hughes and P. Bourdieu, 272-274. Oxford, UK: Blackwell.

Brown, N. J. 2001. Democracy, History, and the Contest over the Palestinian Curriculum. Adam Institute. November. https://home.gwu.edu/ nbrown/Adam_Institute_Palestinian_textbooks.htm Brown, N. J. 2003. Palestinian Politics after the Oslo Accords: Resuming Arab Palestine. Berkeley: University of California Press.

Bryman, A. 2008. Social Research Methods. 3rd ed. Oxford: Oxford University Press.

Bush, K. D., and D. Saltarelli. 2000. The Two Faces of Education in Ethnic Conflict. New York: UNICEF. Davies, L. 2004.

Education and Conflict: Complexity and Chaos. London, UK: RoutledgeFalmer.

Du Bois, W. E. B. 2008. "The Souls of Black Folk (1903)." The Project Gutenberg EBook. https://www. gutenberg.org/files/408/408-h/408-h.htm

Eldén, S. 2012. "Inviting the Messy: Drawing Methods and Children's Voices." Childhood 20 (1): 66-81. Fasheh, M. 1990.

"Community Education: To Reclaim and Transform What Has Been Made Invisible." Harvard Educational Review 60 (1): 19-36.

Freire, P. 1972. Pedagogy of the Oppressed. Translated by M. Bergman Ramos. London, UK: Sheed and Ward.

Fronk, C., R. L. Huntington, and A. Chadwick. 1999. "Educational Attitudes and Trends in Palestine." Educational Studies 25 (2): 217-243.

Galtung, J. 1969. "Violence, Peace and Peace Research." Journal of Peace Research 6 (3): 167-191. Giroux, H. $1983 a$.

Theory and Resistance in Education: A Pedagogy for the Opposition. Amherst: Bergin and Garvey.

Giroux, H. 1983b. "Theories of Reproduction and Resistance in the New Sociology of Education: A Critical Analysis." Harvard Educational Review 53 (3): 257-293.

GCPEA (Global Coalition to Protect Education from Attack). 2014. Education under Attack 2014. New York, NY: GCPEA.

Halstead, M., and S. J. Affouneh. 2006. "Educating the Human Spirit in times of Conflict: The Case of Emergency

Education in Palestine." International Journal of Children's Spirituality 11 (2): 199-215. Harber, C. 2004. Schooling as

Violence: How Schools Harm Pupils and Societies. Oxon: RoutledgeFalmer. INEE (Inter-Agency Network for Education in Emergencies). 2010. INEE Minimum Standards Handbook. New York: INEE.

Khalidi, R. 1997. Palestinian Identity: The Construction of Modern National Consciousness. New York: Columbia University Press.

Lange, M. 2012. Educations in Ethnic Violence: Identity, Educational Bubbles, and Resource Mobilization. Cambridge: Cambridge University Press.

Machel, G. 1996. The Impact of Armed Conflict on Children. New York: UNICEF.

Mahshi, K., and K. Bush. 1989. "The Palestinian Uprising and Education for the Future." Harvard Educational Review 59 (4): 470-484.

van Manen, M. 1998. Researching Lived Experience: Human Science For An Action Sensitive Pedagogy. 2nd ed. Ontario: The Althouse Press.

Miller, J., and B. Glassner. 2010. "The 'Inside' and the 'Outside': Finding Realities in Interviews." In Qualitative Research, edited by D. Silverman, 3rd ed, 131-148. London: Sage.

Moghli, M. A. 2016. Struggle to Reclaim Human Rights Education in Palestinian Authority Schools in Occupied West Bank, an Unpublished Doctoral Dissertation. London: UCL Institute of Education. Novelli, M. 2016. "Capital, Inequality and Education in Conflict-affected Contexts." British Journal of Sociology of Education 37 (6): 848-860. 
Novelli, M., and M. T. A. Lopes Cardozo. 2008. "Conflict, Education and the Global South: New Critical Directions." International Journal of Educational Development 28: 473-488.

Novelli, M., and A. Smith. 2011. The Role of Education in Peacebuilding: A Synthesis Report of Findings from Lebanon, Nepal and Sierra Leone. New York, NY: United Nations Children's Fund.

Pherali, T. 2013. "Schooling in Violent Situations: The Politicization of Education in Nepal, before and after the 2006 Peace Agreement." Prospects 43 (1): 49-67.

Pherali, T. 2016. "Education: Cultural Reproduction, Revolution and Peacebuilding in Conflict- Affected Societies." In Dimensions of Peace: Disciplinary and Regional Approaches, edited by O. P. Richmond, S. Pogodda and J. Ramovic, 296-313. London: Palgrave Macmillan.

Retamal, G., and R. Aedo-Richmond, eds. 1998. Education as a Humanitarian Response. London, UK: Cassell.

Save the Children. 2013. Attacks on Education: The Impact of Conflict and Grave Violations on Children's Futures. London, UK: Save the Children.

Shabaneh, G. 2012. "Education and Identity: The Role of UNRWA's Education Programmes in the Reconstruction of Palestinian Nationalism." Journal of Refugee Studies 25 (4): 491-513.

Silverman, S. 2011. Interpreting Qualitative Data: A Guide to the Principles of Qualitative Research. 4th ed. London: Sage.

Silwadi, N., and P. Mayo. 2014. “Pedagogy under Siege in Palestine: Insights from Paulo Freire.” Holy Land Studies 13 (1): 71-87.

Sinclair, M. 2002. Planning Education in and after Emergencies. Paris: International Institute for Educational Planning [IIEP]

Smith, A. and T. Vaux. 2003. Education, Conflict and International Development. London: Department for International Development [DFID].

Sommers, M. 2002. Children, Education and War: Reaching Education for All (EFA) Objectives in Countries Affected by Conflict. Washington, DC: World Bank.

UNICEF. 2004. The Situation of Palestinian Children in the Occupied Palestinian Territory: In Search of a Better Childhood. Jerusalem: United Nations Children's Fund (UNICEF).

UNRWA (United Nations Relief and Works Agency). 2016. "West Bank Camp Profiles." https://www. unrwa.org/wherewe-work/west-bank/camp-profiles?field=12 